\title{
Symptomatic Hyponatremia after Bowel Preparation: Report of Two Cases and Literature Review
}

\author{
Hiponatrémia Sintomática após Preparação Intestinal: \\ Apresentação de Dois Casos Clínicos e Revisão da \\ Literatura
}

Juliana Moura COSTA $₫ 1$, João Bruno SOARES ${ }^{1}$

Acta Med Port 2017 Nov;30(11):824-826 - https://doi.org/10.20344/amp.8794

\section{ABSTRACT}

Introduction: Bowel preparation for colonoscopy and/or colorectal surgery can cause electrolyte imbalances. The risk of electrolyte imbalances seems to be related to the type of bowel cleansing solution, age of patients and comorbidities.

Case Report: We report two cases of symptomatic hyponatremia (focal neurological signs and coma) after bowel preparation with sodium picosulfate/magnesium citrate for colonoscopy. In both cases, symptoms related to hyponatremia rapidly disappeared after sodium level correction with intravenous administration of hypertonic saline $(3 \% \mathrm{NaCl})$.

Discussion: Electrolyte imbalances are more common with sodium phosphate-based solutions (NaP) and sodium picosulfate/ magnesium citrate, in patients older than 65 , in patients treated with thiazide diuretics, angiotensin-converting-enzyme inhibitor, betablockers or antidepressants and in gastrectomized patients. These patients should use macrogol-based solutions (polyethylene glycol). Conclusion: In patients at risk (patient $>65$ years old, patients taking thiazide diuretics, angiotensin-converting-enzyme inhibitors, beta-blockers and antidepressants and with previous gastrectomy) we recommend macrogol-based solutions.

Keywords: Cathartics/adverse effects; Colonoscopy; Hyponatremia

\section{RESUMO}

Introdução: A preparação intestinal para colonoscopia e/ou cirurgia coloretal pode induzir alterações hidro-eletrolíticas. O risco destas alterações parece estar relacionado com o tipo de preparação intestinal, idade e comorbilidades dos doentes.

Caso Clínico: Os autores apresentam dois casos de hiponatrémia sintomática (sinais neurológicos focais e coma) após preparação intestinal com picossulfato de sódio/citrato de magnésio para colonoscopia. Em ambos os casos, verificou-se resolução completa e rápida do quadro clínico depois da correção da hiponatrémia com solução intravenosa de $\mathrm{NaCl}$ a $3 \%$.

Discussão: Os distúrbios eletrolíticos são mais frequentes nas preparações à base de fosfato de sódio e picossulfato de sódio/ citrato de magnésio, nos doentes com mais de 65 anos ou medicados com diuréticos tiazídicos, inibidores da enzima de conversão da angiotensina, beta-bloqueantes e antidepressivos e em doentes gastrectomizados. Nestes doentes devemos preferir preparações intestinais à base de macrogol (polyethylene glycol).

Conclusão: Em doentes de risco (idade superior a 65 anos, medicados com diuréticos tiazídicos, IECAs, beta-bloqueantes e antidepressivos, e antecedentes de gastrectomia) recomendamos soluções à base de macrogol.

Palavras-chave: Catárticos/efeitos adversos; Colonoscopia; Hiponatrémia

\section{INTRODUCTION}

Bowel preparation for colonoscopy or colorectal surgery can cause electrolyte imbalances like hyponatremia which may lead to serious consequences such as seizures, loss of consciousness, neurological symptoms and eventually coma. ${ }^{1}$ The risk of these electrolyte imbalances seems to be related to the type of bowel cleansing solution, age of the patient and comorbidities. ${ }^{2}$

The authors report two cases of symptomatic hyponatremia after bowel preparation for colonoscopy.

\section{CASE REPORT}

In both cases the bowel preparation for total colonoscopy (for colorectal cancer screening) was done with sodium picosulfate/magnesium citrate (MC-SP).

The first case refers to a 64-year-old female with previous total gastrectomy and depression, taking trazodone and diazepam. She was admitted in our Emergency department due to sudden coma. She presented with a Glasgow coma scale of $5 / 15$. Blood tests showed severe hyponatremia (111 $\mathrm{mmol} / \mathrm{L}$; reference: $136-145 \mathrm{mmol} / \mathrm{L})$, hypokalemia (3.3 $\mathrm{mEq} / \mathrm{L}$; reference: 3.5 - $5.0 \mathrm{mEq} / \mathrm{L})$ and decreased serum osmolality ( $240 \mathrm{mOsm} / \mathrm{kg}$; reference: $289-308 \mathrm{mOsm} / \mathrm{kg}$ ).

The second case refers to a 69 -year-old female with hypertension and dyslipidemia treated with losartan, atenolol and atorvastatin, who was brought to our Emergency department due to sudden dysarthria and paresthesias of her upper limbs. Blood tests revealed moderate hyponatremia $(128 \mathrm{mmol} / \mathrm{L})$ and decreased serum osmolality $(248 \mathrm{mOsm} /$ $\mathrm{kg})$.

In both cases, there was no history of seizures or alcohol consumption, electrocardiogram was normal and brain computerized tomography and magnetic resonance imaging showed no signs of bleeding or other acute brain injuries.

Patients were considered to have neurological symptoms related to bowel preparation-induced severe

1. Gastroenterology Department. Hospital de Braga. Braga. Portugal.

$\triangle$ Autor correspondente: Juliana M. Costa. julianamcosta87@gmail.com

Recebido: 05 de fevereiro de 2017 - Aceite: 27 de junho de 2017 | Copyright @ Ordem dos Médicos 2017 
acute hyponatremia. Thus, they were treated with slow intravenous infusion of hypertonic saline. Complete neurological recovery and normalization of serum sodium levels occurred in 48 hours in the first case and in 24 hours in the second case.

\section{DISCUSSION}

Bowel cleansing is essential to undergo safe and efficient colonoscopy or colorectal surgery. ${ }^{3}$ Although usually safe it may be associated with severe complications. ${ }^{2,4}$

The ideal bowel preparation should be easy to drink while achieving excellent bowel cleansing and minimizing adverse impact over the gastrointestinal tract mucosa and electrolyte balance in order to increase the patient's adherence and safety. ${ }^{5}$

The most common solutions for colonoscopy preparation include polyethylene glycol (PEG), sodium phosphate (NaP) and MC-SP complex. ${ }^{2}$

$P E G$ is an inert polymer of ethyleneoxide, formulated as a nonabsorbable solution designed to pass through the bowel without net absorption nor secretion. Preparations containing PEG do not cause histologic damage in the gastrointestinal tract mucosa. Thus, PEG is considered to be safe for colonic cleansing and complications-free. It is recommended to patients with pre-existing electrolyte imbalances and in patients who cannot tolerate a significant sodium load, namely those with renal failure, congestive heart failure or advanced liver disease with ascites. ${ }^{2}$

$\mathrm{NaP}$ solutions promote an osmotic influx of fluid from the intravascular compartment to the bowel lumen. Therefore, $\mathrm{NaP}$ inevitably carries a possibility of inducing water and electrolyte abnormalities. ${ }^{6}$. Nevertheless, it is a good colon cleanser and usually easier to ingest. ${ }^{7}$

MC-SP complex acts locally in the colon as a combination of a stimulant laxative to increase frequency and strength of peristaltsis (sodium picosulfate component) and as an osmotic laxative to retain fluid in the colon (magnesium citrate component). ${ }^{2}$ Compared with PEG and $\mathrm{NaP}$ solutions, it has similar bowel cleaning efficacy but the patient's compliance has been reported to be better than with PEG and NaP. ${ }^{8} \mathrm{MC}-\mathrm{SP}$ complex and $\mathrm{NaP}$ have been associated with numerous electrolyte imbalances ${ }^{1}$ as well as colonic mucosa inflammation. ${ }^{2}$

Electrolyte imbalances are well-recognized complications of bowel preparations and include hyponatremia, hypomagnesemia, hypocalcemia and hypophosphatemia. Whilst hyponatremia is the most frequent one, being reported in up to $7.5 \%-8.8 \%$ patients, it rarely achieves clinical significance..$^{4,9}$

Hyponatremia is defined as a serum sodium level less than $135 \mathrm{mEq} / \mathrm{L}$. Symptoms do not normally occur unless the serum sodium level is lower than $120 \mathrm{mEq} / \mathrm{L}$. However, symptoms might occur at a level above that when the rate of decrease of the serum sodium level is very abrupt. The symptoms range from milder ones, such as loss of appetite, nausea, and vomiting, to more severe ones, such as seizure, lethargy, coma, and even death. If the patient presents with severe neurological symptoms or a serum sodium concentration less than $110 \mathrm{mEq} / \mathrm{L}$, urgent treatment is required. ${ }^{5}$

Bowel preparation-induced coma is uncommon and there are only four cases reported in the literature. The age of these patients ranged from 64 to 80 years, one patient was taking thiazide diuretics and beta blockers, another patient had a previous history of gastrectomy, two patients used $\mathrm{NaP}$ solutions and two other patients used MC-SP complex. ${ }^{5,6,9}$

Because of the osmotic activity of the chemical contents of the NaP and MC-SP complex, these solutions induce water and electrolyte abnormalities. ${ }^{10}$ For this reason, elderly individuals and patients with impaired renal function, liver cirrhosis or congestive heart failure are more prone to these events. ${ }^{6}$

Studies that investigated the risk of hyponatremia in elderly patients taking PEG and MC-SP, showed that the incidence of hyponatremia was higher in patients taking MC-SP, even though there were no significant differences in terms of neurological symptoms or length of hospital stay. ${ }^{11}$ In order to prevent hyponatremia, patients should be instructed to take MC-SP with a generous amount of water. In addition, care should be taken when using MCSP complex in patients with impaired renal function, heart failure, inflammatory bowel disease ${ }^{12}$ and patients taking drugs for hypertension and depression. ${ }^{13}$

Gastrectomy is also considered a risk factor for hyponatremia related to bowel preparation. The rapid emptying of bowel preparation solutions into the small intestine with the addition of accelerated bowel movements may result in an exaggerated intravascular volume contraction and hence in acute hypovolemic hyponatremia. ${ }^{6}$ Furthermore, in states of hypovolemia there is a stimulation of water retention through arginine vasopressin (AVP) stimulation of aquaporin (AQP) expression in the renal principal cell, worsening hyponatremia (dilution). ${ }^{14}$

Until now, there is no evidence that 'split-dose' regimens avoid or decrease electrolyte imbalances; the advantage of these regimens is the better tolerability with equal effectiveness when compared to standard regimes. ${ }^{15}$

Bowel preparation-induced hyponatremia should be treated with slow intravenous infusion of hypertonic saline aiming to increase sodium level at a rate of $0.5 \mathrm{mmol} / \mathrm{L} / \mathrm{h}$, not exceeding $12 \mathrm{mmol} / \mathrm{L}$ in the first 24 hours nor $18 \mathrm{mmol} / \mathrm{L}$ in the first 48 hours to avoid osmotic demyelination and brain edema. Usually, it takes $48 \mathrm{~h}-72 \mathrm{~h}$ for full clinical and sodium balance recovery. ${ }^{16}$

Our report calls the attention to the importance of the patient's medical history when choosing a bowel preparation solution. Moreover, in patients presenting with neurological symptoms while taking these solutions, we should evaluate serum electrolytes and start treatment immediately. 


\section{CONCLUSION}

Hyponatremia may be a complication of bowel cleansing. It is usually asymptomatic but sometimes may lead to serious although reversible manifestations such as coma. The risk of hyponatremia appears to be related not only to age and comorbidities but also to the type of product used to clean the bowel. This risk is higher with NaP-based and MC-SP complex preparations. Therefore, in patients at risk (patient > 65 years old, patients taking thiazide diuretics, ACE inhibitors, beta-blockers and antidepressants and with previous gastrectomy) we recommend macrogol-based solutions.

\section{PROTECTION OF HUMAN AND ANIMAL SUBJECTS}

The authors declare that the procedures followed were in accordance with the regulations of the relevant clinical research ethics committee and with those of the Code of Ethics of the World Medical Association (Declaration of Helsinki).

\section{CONDIDENTIALLY OF DATA}

The authors declare that they have followed the protocols of their work center on the publication of patient data.

\section{RIGHT TO PRIVACY AND INFORMED CONSENT}

The authors have obtained the written informed consent of patients or subjects mentioned in the article. The corresponding author is in possession of this document.

\section{CONFLICTS OF INTEREST}

The authors have no conflicts of interest to declare.

\section{REFERENCES}

1. Frizelle FA, Colls BM. Hyponatremia and seizures after bowel preparation: report of three cases. Dis Colon Rectum. 2005;48:393-6.

2. Saltzman JR, Cash BD, Pasha SF, Early DS, Muthusamy VR, Khashab MA, et al. Bowel preparation before colonoscopy. Gastrointest Endosc. 2015;81:781-94.

3. Hassan C, Bretthauer M, Kaminski MF, Polkowski M, Rembacken B, Saunders B, et al. Bowel preparation for colonoscopy: European Society of Gastrointestinal Endoscopy (ESGE) guideline. Endoscopy. 2013;45:142-50.

4. Gabriel JC, Muñoz SR, de la Cruz BJ, Carretero Gómez JF, Yagüe MT, Manzano Alonso ML, et al. Electrolytic disturbances and colonoscopy: bowel lavage solutions, age and procedure. Rev Esp Enferm Dig. 2003;95:870-5.

5. Cho YS, Nam KM, Park JH, Byun SH, Ryu JR, Kim HJ. Acute hyponatremia with seizure and mental change after oral Sodium Picosulfate/Magnesium Citrate bowel preparation. Ann Coloproctol. 2014;30:290-3.

6. Liu SY, Cheung FK, Siu WT, Ng EK. Hyponatremic convulsion after oral Sodium Phosphate for bowel preparation in a patient with previous gastrectomy. Endoscopy. 2006;38:854-5.

7. Regev A, Fraser G, Delpre G, Leiser A, Neeman A, Maoz E, et al. Comparison of two bowel preparation for colonoscopy: sodium picosulphate and magnesium citrate versus sulphate free polyethylene glycol lavage solution. Am J Gastroenterol. 1998;93:1478-82.

8. Barkun A, Chiba N, Enns R, Marcon M, Natsheh S, Pham C, et al. Commonly used preparations for colonoscopy: efficacy, tolerability, and

safety: a Canadian Association of Gastroenterology position paper. Can J Gastroenterol. 2006;20:699-710.

9. Dillon CE, Laher MS. The rapid development of hyponatraemia and seizures in an elderly patient following sodium picosulfate/magnesium citrate (Picolax). Age Ageing. 2009;38:487.

10. Haris A, Demeter P, Tóth I, Polner K. Severe hyponatremia and comatose state during colonoscopy preparation. Orv Hetil. 2010;151:828-31.

11. Lieberman D, Ghormley J, Flora K. Effects of oral sodium phosphate colon preparation on serum electrolytes in patients with normal serum creatinine. Gastrointest Endosc. 1995;43:467-9.

12. Lawrance IC, Willert RP, Murray K. Bowel cleansing for colonoscopy: prospective randomized assessment of efficacy and of induced mucosal abnormality with three preparation agents. Endoscopy. 2011;43:412-8.

13. Weir MA, Fleet JL, Vinden C, Shariff SZ, Liu K, Song $H$, et al. Hyponatremia and sodium picosulfate bowel preparations in older adults. Am J Gastroenterol. 2014;109:686-94.

14. Forde H, O'Shea T, Davenport C, Smith D. Acute symptomatic hyponatremia following sodium picosulfate/magnesium citrate as bowel preparation for colonoscopy: a case series. Case Rep Clin Med. 2014;3:101-4.

15. Pearce D, Soundararajan R, Trimpert C, Kashlan OB, Deen PMT, Kohan DE. Collecting duct principal cell transport processes and their regulation. Clin J Am Soc Nephrol. 2015;10:135-46.

16. Lee KJ, Park HJ, Kim HS, Baik KH, Kim YS, Park SC, et al. Electrolyte changes after bowel preparation for colonoscopy: A randomized controlled multicenter trial. World J Gastroenterol. 2015;21:3041-8. 